\title{
DEIXIS ON TRIBUNNEWS.COM "THE STORY OF ADE JIGO WAS ROLLED UP BY THE TSUNAMI 2018"
}

\author{
Jasmine Adinda Putri ${ }^{1}$, Yana ${ }^{2}$ \\ ${ }^{1}$ IKIP Siliwangi \\ ${ }^{2}$ IKIP Siliwangi \\ ${ }^{1}$ Jasmineadindaputri@students.ikipsiliwangi.ac.id, ${ }^{2}$ Yanaenglish.edu@ gmail.com
}

\begin{abstract}
This research aims to identify words contain the deixis from Tribunnews.com and then describes the factors of the deixis that also give more understanding to the reader about types of deixis which are used in tribunnews.com. The researchers used a descriptive qualitative method to analyze the words contained in Tribunnew.com. Data collection used by the researchers is documentation, there are: collecting the data, reading and observing, finding the data, putting sign and making a checklist on it, taking and presenting them in the data display, and finding conclusions. Moreover, the researchers found the deixis in the news that the word of I $(24.51 \%)$, we $(1.96 \%)$, he $(8.82 \%)$, calling name $(6.86 \%)$, kindship lexemes $(32.35 \%)$. The word of place or location like a beach, Krakatau mountain, etc is spatial deixis is a place $(9.80 \%)$ and adverb of place $(8.82 \%)$. And the last the use of time such as then, now, soon, day, today, etc is the temporal deixis there are deictic Modifier (2.94\%) and non-deictic (3.92\%). From this research, the researchers conclude that online article creates a narrative in the news that discusses natural disasters, uses a lot of deixes to the person, place, and time.
\end{abstract}

Keywords: Deixis, Tribunnews, Pragmatics

\section{INTRODUCTION}

Nowadays, language is indeed used in every aspect of human life. And it is not only used in everyday conversation but also used in certain conversations. There are two kinds of language used by humans to communicate, there are spoken and written language. Language often brings up the meaning of utterance or expressions containing other contexts which are called pragmatic. According to Melchers et al (2019) "Pragmatics is concerned with language in use: how we use language in particular circumstances to achieve particular ends. It is concerned with appropriacy rather than correctness". In other words, as Levinson (1983:9) cited in Pertiwi (2019), states Pragmatics is the study of those relations among language and context that are grammaticalized, encoded in the structure of a language. Furthermore, according to Finch (2000), Pragmatics focuses not on what people say but how they say it and how others interpret their utterances in a social context.

So, it can be seen that knowing the context in the language is important. Every speaker and listener must have a sensitive connection to the topic being discussed. This can help people understand the meaning of the conversation more easily. Besides that, good communication occurs when the speaker and the listener understand it well. To understand human interaction, one must understand the 'interactional' meaning expressed in speech. One of them in pragmatics is deixis.

Deixis in linguistics is a sentence or word that shows contextual information. According to Levinson (1983) in Viahapsari \& Parmawati (2020) deixis is a word which its reference always moves or changes depending on the contextto indicate person, place, time, social distinction, 
and role in discourse.The kinds of deixis there are person deixis, spatial deixis, and temporal deixis, discourse deixis, and social deixis. Deixis concerns the manners in which that language encodes data about the setting in which expressions happen and the manners by which the interpretation of utterance relies upon the analysis of the specific circumstance (Strazny, 2005, p. 260 cited in Hangalo (2019)). Additionally, according to Nordquist (2017) cited in Syam (2018), Deixis is expressed in English by the method of personal pronouns, demonstratives, adverbs, and tense. A deictic expression or deixis is a word or phrase (for example; this, that, these, those, now, then, here) that focuses on the time, place, or situation in which a speaker is speaking. Deixis is a site and utilized for analyzing individuals, objects, occasion, process, or an action that is being spoken or referred to space and time dimension.

Deixis can be found in the online article, the researchers feel that there are linguistic languages given that in linguistics there are many deixes in the news such as people deixis, spatial deixis, and temporal deixis. Moreover, one of the interesting and popular news is Tribunnews.com that contained on YouTube or articles on the internet, which is famous for a semi-formal situation which usually causes news themes to occur, making the news pay more attention to the way they use language to avoid misunderstandings. Because this online article is a complex medium that can provide deixis, therefore it can be made a part of the researchers' analysis.

This study aims to find out the researchers' curiosity in working on topics in the field of linguistics, especially regarding deixis, also provides more explanation to readers about the types of deixis used at tribunnews.com.

In this research, analyzed deixis in pragmatics indicates that there are three types of deictic words, namely: Person deixis, Spatial deixis, and Temporal deixis. Which follows are the explanation of each.

\section{Person Deixis}

Person deixis is utilized to specify people and it functions on a basic three-section division, exemplified by the individual pronouns for example, 'I', 'you', 'he', 'she', 'it', 'we', and 'they'. According to Cruse (2000) as cited in Asmarita \& Haryudin (2019) person deixis involves the speaker, known as the first person, the addressee, known as the second person, and other significant participants in the speech situation, neither speaker nor listener, known as the third person. Furthermore, as Abdulameer (2019), states that person deixis refers to grammatical classes of people involved in an utterance and expressed by persons: first person deixis (I, we), second person deixis (you) and third-person deixis (he, she, it and they). In the Tribunnews.com found the usage of person deixis, both the first and second person deixis or third person. The first person deixis using the form I, and we. Second person deixis using a kindship lexeme (Child, Wife, Mom, Dad, Ade Jigo, Aa Jimmy, Meyuza Zainal Arifin) and calling names (Caregiver, employee, Seventeen, LawakJigo). Then third-person deixis using the form he, is as singular.

\section{Spatial Deixis}

Spatial deixis is related to the concept of distance and place. This type of deixis is utilized to highlight an area where an element is referred to is in a specific situation. As Cummings (2006 p.26) states in Wiguna, Anggraeni, Nuramalia, \& Sadikin (2018 p. 134), Place Deixis is also described as Spatial Deixis, where the relative area of people and things is being demonstrated. It usually is expressed in: this, these, that, those, there, and here. According to Houck (2002) cited in Eightinauli \& Purwani (2019), spatial deixis is used to refer the location of people and things and spatial deixis usually consists of here, there; come, go; bring, take; this, that, etc. Therefore, spatial deixis can refer to show the object that imagines the location. 


\section{Temporal Deixis}

Temporal deixis concerns the encoding of temporal focuses to the time at which an utterance was spoken. According to Thao (2020), temporal deixis refers to indicate a time for example now, then, next week, last month, and so on for interpreting most of the deictic expressions that the speakers have in their mind. However, Setiakawanti \& Susanti (2018 p.759), mention that temporal deixis shows the orientation or position of actions and events in time.

\section{METHOD}

This research is a descriptive qualitative method. Based on Arikunto (2010 p.3) the descriptive research aims only to describe a phenomenon without causing it to change. It describes, explains, classifies, and analyzes the study by discourse analysis. In this research, the researcher analyzes the data of deixis. The deixis types and references used by the writing form Tribunnews.com post in January 2019. The object analysis of the research is deixis and reference of deixis provided by Tribunnews 'The story of Ade Jigo Was Rolled Up by The Tsunami 2018'. The source of data by Tribunnews post in January 2019. The data of this research are sentences containing deixis words. Method of data collection that is used by the researchers is documentation strategy, such as: collecting the data, reading and observing the data, finding the data, putting sign and making a checklist on it, taking the data and presenting them in the data display, and finding conclusions.

\section{RESULTS AND DISCUSSION}

\section{Results}

In online articles Tribunnews.com the researchers found three types of deixis. The researchers calculated the frequency of this deixis and the result are:

\section{The Use of Person Deixis}

The tables below show the person deixis by Tribunnews.com 'The story of Ade Jigo Was Rolled Up by The Tsunami 2018'

Table 1.

Person Deixis Pointing to First Person

\begin{tabular}{ccc}
\hline $\begin{array}{c}\text { Person Deixis } \\
\text { Expressions }\end{array}$ & $\begin{array}{c}\text { First Singular } \\
\text { I / My }(\text { Saya })\end{array}$ & $\begin{array}{c}\text { First Plural } \\
\text { We }(\text { Kita })\end{array}$ \\
\hline Percentage $(\%)$ & $24.51 \%$ & $1.96 \%$ \\
\hline
\end{tabular}

Table 2. Person Deixis Pointing to Second Person

\begin{tabular}{ccc}
\hline $\begin{array}{c}\text { Person Deixis } \\
\text { Expressions }\end{array}$ & Kindship Lexemes & Calling Names \\
\hline Percentage $(\%)$ & $32.35 \%$ & $6.86 \%$ \\
\hline
\end{tabular}

Table 3. Person Deixis Pointing to the Third Person

\begin{tabular}{cc}
\hline $\begin{array}{c}\text { Person Deixis } \\
\text { Expressions }\end{array}$ & He \\
\hline Percentage $(\%)$ & $8.82 \%$ \\
\hline
\end{tabular}


As is shown in Table 1, according to Putri \& Budiarsa (2018 p. 702), Person deixis is can be three categories: First Person Deixis, Second Person Deixis, and Third Person Deixis. In pointing to the first person or the speakers themselves, most speakers tend to use 'I' because that expression is the formal expression. Also, another important participant in personal deixis besides speaker and hearer that are known as the third person. And they also often use 'We' when pointing to themselves and other people. But the word "We" is only said a little because most often discuss themselves.

The Word of I (Saya) :

"I go backstage to clean up, I haven't changed my costume, I took my child, I took a walk to the front of the stage, my wife was feeding my first child."

\section{The Word of We (Kita) :}

"Seventeen has entered the second song, we still watch it still enjoys. And I was able to go right and left-right and left with my little child. "- Ade taught on Thursday.

As is shown by the Table 2, that the utterance from the tribunnews.com frequently use kindship lexemes and calling names to point to the second person or the addressee because kindship lexemes are a formal expression in which they give more feeling of solidarity, but, at the same time, they are more polite than ' $A n d a$ ' in Bahasa. Moreover, by using kindship lexemes and calling names, the utterances may become softer.

\section{The Word of Kinship Lexemes and Calling Names :}

"According to Ade Jigo, just before the tsunami came, he and Aa Jimmy, who were members of the Jigo comedy group, were hosting the program at one of the events in Tanjung Lesung. Ade Jigo was not alone at that time, he brought his wife and children to enjoy the atmosphere of the beach while he worked. Ade together with his youngest son at the time was watching the band Seventeen who were performing"

"At that time, $\underline{\text { Aa Jimmy }}$ and his wife and children were backstage, along with $\underline{\text { Ade's wife, }}$ Meyuza Zainal Arifin"

"His first child and caregiver were at the front of the stage, shortly after that he saw seawater high enough towards the mainland."

" One line, the first father in front of me saw him come out and then I was the second. I asked the gentleman to the father who said 'sir, please hold my child, I am not strong enough' I said so, the father held me just out," "Finally I was taken to the hotel employee dorm, then I made a video posting on Instagram, " he said.

As is shown in Table 3, most speakers tend to use 'He' when pointing to the third person singular.

\section{The Word of He :}

"Ade Jigo was not alone at that time, he brought his wife and children to enjoy the atmosphere of the beach while he worked", "And he talked about anything, saying to the caregiver I saw Mount Krakatoa" was it red on it?" "One queued, the first father, in front of me, saw him coming out, and then I was the second." Until finally Ade and the youngest son survived, he hurried to the hotel to change his son's clothes ". 
According to Ade Jigo, shortly before the tsunami came, he and Aa Jimmy, who were members of the Jigo comedy group, were present at one of the events in Tanjung Lesung ".

"He brought his wife and children to enjoy the atmosphere of the beach while he worked."

"Ade also ran but not until the steps he was rolled up to the end of the wave until finally entering a sewer".

\section{The Use of Spatial Deixis}

The tables below show the spatial deixis by Tribunnews.com 'The story of Ade Jigo Was Rolled Up by The Tsunami 2018'

Table 4.

Spatial Deixis Expressions Pointing to Place and Adverb Place

\begin{tabular}{ccc}
\hline $\begin{array}{c}\text { Spatial Deixis } \\
\text { Expressions }\end{array}$ & Place & Adverb of Place \\
\hline Percentage $(\%)$ & $9.80 \%$ & $8.82 \%$ \\
\hline
\end{tabular}

As is shown in Table 4, the news uses a lot of places when the news wants to mention the location. But sometimes mention the adverb of place to mention the place.

\section{The Word of Place :}

"According to Ade Jigo, shortly before the tsunami came, he and Aa Jimmy, who were members of the Jigo comedy group, were present at one of the events in Tanjung Lesung. Ade Jigo was not alone at that time, he brought his wife and children to enjoy the atmosphere of the beach while he worked ".

"When I went down, I went to the backstage to clean up, I haven't changed my costume, I took my child, I took a walk to the front of the stage, my wife fed my first child"

"I had said my observer saw Mount Krakatau"

"Ade also ran but it wasn't until five steps that he had rolled up the waves until he finally entered a sewer. "

"Until finally Ade and his youngest child survived, he hurried to the hotel to change his son's clothes."

"Finally, I was taken to the hotel employee dorm before I took the video posting on Instagram," he said.

The Word of Adverb of Place to tell what happened. The place description is usually located in the main verb after the modified clause. That can't change adjectives or other adverbs.

"When I go down, I go backstage to clean up, I haven't changed my costume, I took my child, I took a walk to the front of the stage, my wife gave me my first child. " At that time, Aa Jimmy and his wife and children were backstage, along with Ade's wife, Meyuza Zainal Arifin.

His first child and caregiver were at the front of the stage, shortly after that he saw seawater high enough towards the mainland.

"I have seen the water coming. But the position of the water is approximately 2 meters, not the high one because I position beside," he said.

"I take a walk to the front of the stage"

Adverbs of place that end in -where express of an idea of location without specifying a specific direction (I had seen water coming). 


\section{The Use of Temporal Deixis}

The tables below show the temporal deixis by Tribunnews.com 'The story of Ade Jigo Was Rolled Up by The Tsunami 2018'

Table 5.

Temporal Deixis Expressions Pointing to Deitic Modifier and Non-deictic.

\begin{tabular}{ccc}
\hline $\begin{array}{c}\text { Spatial Deixis } \\
\text { Expressions }\end{array}$ & Deictic Modifier & Non-Deictic \\
\hline Percentage $(\%)$ & $2.94 \%$ & $3.92 \%$ \\
\hline
\end{tabular}

As is shown in Table 5, in this news more often use the deictic modifier and non-deictic for mention the word of temporal or time.

\section{The Word of Deitic Modifier:}

"Then my wife said, "Dad, this is to invite the children to watch, bunda will wait"

"Seventeen has entered the second song, we are still watching, still enjoying it, and I had a walk right-left-right-left with my little child," said Ade, Thursday (1/3/2019).

"Until finally Ade and his youngest child survived, he rushed to the hotel to change his son's clothes".

a. Terus (Then): The adverbials time, an utterance from Ade Jigo to tell his wife before saying something.

b. Kamis (Thursday): The adverbials time, show the clarification when the interview happened.

c. Bergegas (Hurry): The time was showed what there to do after the tsunami disaster

\section{The Word of Non-Deictic :}

"But it was unexpected that the tsunami disaster occurred at that time.

"Ade and his youngest son were watching the band Seventeen who were performing."

"I'm with my child, hug, how do I survive with my child, and I'm over five minutes later, sorry, yeah, I've touched all kinds of things, there are iron, walls, wood, and I'm sorry there are humans too" - he said

"A rope became Ade's savior at that time, he continued to hold on until the sewer door of the pool water was opened".

Ade Jigo was utterance about the chronologist is considered distal as the situation does not exist, and the journalist's share in print media utterance in the situations still in progress.

\section{Discussion}

The researchers chose deixis to analyze scripts by online articles Tribunnews.com. The researchers have already checked three types of deixis, namely: person deixis, spatial deixis, and temporal deixis.

According to the research, the researchers found:

1. Person deixis in :

a. The First-person there are; I, my, and we.

b. The Second person there are; Child, Wife, Mom, Dad, Ade Jigo, Aa Jimmy, Meyuza Zainal Arifin, Caregiver, employee, Seventeen, and LawakJigo. 
c. The Third-person there is; He.

2. Spatial deixis there are; Tanjung Lesung, beach, backstages, stage, mount Krakatau, sewer, hotel, dorm, front, and coming.

3. Temporal deixis there are; then, Thursday, rushed, at that time, were, and five minutes later.

In this research, there are many deixes of a person compared to another deixis that is because in this online article tribunnews.com more often uses the words deixis of person, to describe the situation there.

\section{CONCLUSION}

From this study, the researchers found the deixis in this online article. Seen from the data it can be concluded that the word of I, we, he, himself, kindship lexemes is the most of person deixis which uses in the news. The word of place or location like a beach, Krakatau mountain, etc is the spatial deixis. The last the use of time such as then, now, soon, day, today, etc is the temporal deixis. From this study also, the researcher concludes that the news writer on online articles creates a narration of disaster news many use deixes to the person, place, and time.

\section{ACKNOWLEDGMENTS}

Praise to be Allah SWT who has enabled the researcher to finish this article. Peace and salutations are always for Rasulullah SAW. During completing this article, the researcher obtained many help, suggestions, and motivations from many people. For that reason, the researcher would like to express her gratitude to:

1. Yana, S.Pd., M.Hum as the first supervisor who has kindly given invaluable guidance, suggestion, advice, and support in completing this project;

2. My beloved parents (Ayi Jajat Sujari and R. Fenty Rustiaty), who always give me pray, inspiration and make me motivated to finish this project;

\section{REFERENCES}

Abdulameer, T. A. S. A. (2019). A Pragmatic Analysis of Deixis in a Religious Text. International Journal of English Linguistics, 9(2), 292. Https://Doi.Org/10.5539//jel.V9n2p292

Arikunto, S. (2010). Prosedur Penelitian: Suatu Pendekatan Praktik. 3.

Asmarita, A., \& Haryudin, A. (2019). An Analysis Deixis in Ridwan Kamil' S Speech at the Asia Africa Conference (KAA). Project (Professional Journal of English Education), 2(5), 622-627.

Eightinauli, S., \& Purwani, R. (2019). Spatial Deixis “ Here ” In Movie Script Remember Me By William Fetters And Jenny Lumet. 215-220.

Finch, G. (2000). Linguistic Terms And Concepts. Linguistic Terms and Concepts. Https://Doi.Org/10.1007/978-1-349-27748-3

Hangalo, S. N. (2019). A Critical Analysis of Deictic Referencing: A Case Study of Selected Editorials in the Namibian Newspaper. The University Of Namibia.

Pertiwi, D. P. (2019). A Pragmatics Study of Deixis Used by English Teacher.

Putri, A., \& Budiarsa, M. (2018). The Analysis Of Deixis In The Novel The Fault in Our Stars By John Green. Jurnal Humanis, 22(3), 697-703. 
Https://Doi.Org/10.24843/Jh.2018.V22.I03.P19

Setiakawanti, R. N., \& Susanti, E. (2018). Analysis Pragmatic Study on Deixis in the Articles Jakarta Sport. Project (Professional Journal Of English Education), 1(6), 757-762.

Syam, A. T. (2018). A Discourse Analysis of German Fairy Tale "Rapunzel "Written by The Brothers Grimm. 13(October).

Thao, N. Van. (2020). An Analysis of Deixis to Song Lyrics “ My Heart Will Go On ” By Celine Dion. 6(2), 23-26. Https://Doi.Org/10.11648/J.Cls.20200602.12

Tribunnews.Com. (N.D.). Cerita Ade Jigo Saat Tergulung Tsunami Hingga Temukan Sang Istri Tak Bernyawa.

Tribunseleb. (N.D.). Cerita Ade Jigo Saat Tergulung Tsunami Hingga Temukan Sang Istri Tak Bernyawa.

Viahapsari, E., \& Parmawati, A. (2020). Analysis The Type Of Deixis In The Main Character On The Movie I Leave My Heart In Lebanon. PROJECT (Professional Journal of English Education), 3(3), 388-394.

Wiguna, A., Anggraeni, H., Nuramalia, R., \& Sadikin, I. S. (2018). Deixis in Maleficent Movie Script. Project (Professional Journal Of English Education), 1(2), 133-138. 